\title{
PENGEMBANGAN E-MODUL BERBASIS WEB SEBAGAI BAHAN AJAR FISIKA PADA MATERI GELOMBANG BUNYI DI SMA
}

\author{
Miya Novitasari*, Connie, Eko Risdianto
}

Program Studi S1 Pendidikan Fisika Universitas Bengkulu

Jalan WR. Supratman, Kandang Limun Bengkulu

e-mail*: miyanovitasari1811@gmail.com

\begin{abstract}
ABSTRAK
Penelitian ini merupakan penelitian dan pengembangan (R\&D) yang bertujuan untuk menghasilkan e-modul berbasis web sebagai bahan ajar fisika pada materi gelombang bunyi. Model pengembangan yang digunakan yaitu model 3 D dengan langkah-langkah Define, Design, dan Develop. Tahap define terdiri dari observasi, identifikasi masalah, dan pengumpulan data. Pada tahap design terdiri dari memilih media pembelajaran, memilih format bahan ajar, dan rancangan awal bahan ajar elektronik. Tahap develop terdiri dari validasi judgement ahli (dosen) dan praktisi (guru). Subjek penelitian adalah peserta didik SMAN 2, 4 dan 6 Kota Bengkulu. Validasi dilakukan oleh 2 judgement ahli dan 2 praktisi untuk menilai produk yang dikembangkan dari aspek isi, penyajian, bahasa dan media. Berdasarkan hasil uji validasi, aspek isi sebesar 79\% dengan kategori sangat baik, aspek penyajian sebesar 77\% dengan kategori sangat baik, aspek bahasa sebesar 79\% dengan kategori sangat baik dan aspek media sebesar 75\% dengan kategori baik. Berdasarkan hasil tersebut, dapat disimpulkan bahwa e-modul berbasis web yang dihasilkan sudah layak diuji cobakan dengan persentasi rata-rata sebesar $78 \%$ yang termasuk dalam kategori sangat baik.
\end{abstract}

Kata Kunci: Pengembangan E-modul, Bahan Ajar, Gelombang Bunyi

\section{ABSTRACT}

This research was a research and development $(\mathrm{R} \& D)$ that aimed to produce web-based e-modules as physics teaching materials on sound wave material. The development model used was a 3 D model with Define, Design, and Develop steps. The define stage consists of observation, problem identification, and data collection. At the design stage consists of choosing learning media, choosing the format of teaching materials, and the initial design of electronic teaching materials. The develop phase consists of validating expert judgment (lecturers) and practitioners (teachers). The research subjects were students of SMAN 2, 4 and 6 Bengkulu City. Validation was carried out by 2 expert judgments and 2 practitioners to assess products developed from the aspects of content, presentation, language and media. Based on the results of the validation test, the content aspect was $79 \%$ with a very good category, the presentation aspect was $77 \%$ with a very good category, the language aspect was $79 \%$ with a very good category and the media aspect was $75 \%$ with a good category. Based on these results, it can be concluded that the resulting web-based e-module was worth testing with an average percentage of $78 \%$ which was included in the excellent category.

Keywords: Development of E-modules, Teaching Materials, Sound Waves

\section{PENDAHULUAN}

Dalam era globalisasi saat ini hampir semua bidang kehidupan dituntut untuk menyesuaikan zaman. Hal ini agar bidang-bidang kehidupan tidak ketinggalan zaman akibat perkembangan di era globalisasi. Salah satunya yaitu pada bidang pendidikan (1).

Pendidikan adalah usaha sadar dan terencana untuk mewujudkan suasana belajar dan proses pembelajaran agar peserta didik secara aktif mengembangkan potensi dirinya untuk memiliki kekuatan spiritual keagamaan, pengendalian diri, kepribadian, kecerdasan, akhlak mulia, serta keterampilan yang diperlukan dirinya, masyarakat, bangsa dan negara. Selain di dalam Undangundang, karakter positif juga banyak ditulis dalam visi dan misi lembaga pendidikan (2). Pendidikan identik dengan upaya melakukan transfer pengetahuan dengan merealisasikan program pembelajaran dalam bentuk proses belajar mengajar. Proses kegiatan belajar mengajar merupakan 
interaksi diantara peserta didik dan guru dalam rangka mencapai tujuan pembelajaran yang telah ditetapkan (3).

Perkembangan teknologi informasi dan komunikasi atau Information and Communication (ICT) memberikan dampak besar dalam berbagai sendi kehidupan, termasuk dunia pendidikan yang memberikan banyak tawaran dan pilihan dalam menunjang proses pembelajaran (4).

Proses pembelajaran adalah hal yang sangat penting di dalam proses pendidikan. Banyak hal yang harus diperhatikan untuk memilih model, metode, media dan bahan ajar yang akan diterapkan dalam proses pembelajaran di kelas yaitu karakteristik materi, karakteristik siswa, saran dan prasarana serta kemampuan guru dalam menerapkannya(5).

Media pembelajaran merupakan suatu bagian integral dari proses pembelajaran di sekolah. Peran media sangat dibutuhkan dalam pembelajaran sebagai salah satu alat bantu penyalur pesan dari pemberi pesan (guru) ke penerima pesan (perserta didik). Salah satu pemanfaatan media pembelajaran yang digunakan sebagai perantara dalam pembelajaran Fisika adalah bahan ajar (6).

Modul merupakan bentuk bahan ajar yang pengorganisasian materi pelajarannya memperhatikan fungsi pendidikan. Artinya, melalui modul suatu pembelajaran diharapkan mampu membawa peserta didik pada kompetensi dasar yang diharapkan (7).

Modul Elektronik Berbasis Web dapat dimaknai sebagai bahan ajar modul yang ditampilkan menggunakan piranti elektronik berupa Web. Beberapa piranti elektronik yang dapat digabungkan untuk membangun modul elektronik semacam ini adalah Contain Managemen System (CMS) Wordpress sebagai tempat menyajikan materi, situs berbagi video Youtube yang memungkinkan untuk menyajikan informasi berupa video, dan Quiz Management System (QMS) Classmarker yang dapat menyajikan sistem penilaian otomatis berbasis web (8).

Selain bahan ajar, dalam dunia pendidikan juga dibutuhkan media, media adalah perantara atau pengantar pesan dari pengirim ke penerima pesan. Istilah media yang digunakan dalam bidang pengajaran atau pendidikan disebut dengan media pendidikan atau media pembelajaran (9). Penggunaan media pembelajaran dalam proses pembelajaran bisa membangkitkan motivasi dan rangsangan kegiatan belajar, membangkitkan keinginan dan minat yang baru serta membawa pengaruh-pengaruh psikologi terhadap siswa (10).

Berdasarkan hasil observasi di SMAN 2 Kota Bengkulu, SMAN 2 Kota Bengkulu membutuhkan bahan ajar berupa e-modul dengan materi yang mengacu pada kurikulum 2013 dan pembelajaran yang mengacu pada perkembangan teknologi dan komunikasi. Untuk mengatasinya, penulis mengembangkan modul berbasis web. Adapun modul yang dikembangkan menggunakan aplikasi web berupa website. Modul tersebut dipilih karena dinilai cukup menarik untuk memotivasi siswa dalam kegiatan proses pembelajaran. Modul yang dikembangkan tidak membuat siswa merasa cepat bosan dengan tampilan dibuat sesuai materi yang diajarkan dan siswa dapat dengan mudah memperluas materi yang ada di dalam website menggunakan fasilitas hyperlink. Alasan lainnya yang mendasari pengembangan modul berbasis web adalah untuk memanfaatkan fasilitas internet yang ada di SMAN 2 Bengkulu.

Penelitian yang relevan dengan penelitian ini adalah penelitian yang dilakukan oleh Taufik Solihudi JH (2018) tentang "Pengembangan E-Modul Berbasis Web Untuk Meningkatkan Pencapaian Kompetensi Pengetahuan Fisika Pada Materi Listrik Statis Dan Dinamis Sma" menyatakan bahwa Salah satu media yang dapat dikembangkan adalah media pembelajaran dengan memanfaatkan berbagai keunggulan yang dimiliki oleh teknologi komputer, misalnya dengan menggunakan web (11). Penelitian lainnya yaitu dilakukan oleh Purwaningtyas, Wasis D. Dwiyogo, Imam Hariyadi tentang "Pengembangan Modul Elektronik Mata Pelajaran Pendidikan Jasmani, Olahraga dan Kesehatan Kelas XI Berbasis Online dengan Program Edmodo" menyatakan bahwa Walaupun dengan terkadang terdapat keterbatasan untuk penggunaan teknologi seperti kebutuhan untuk pemeliharaan dan hilangnya konektivitas, namun demikian mengajar secara online (berbasis web) memberdayakan siswa dan memaksimalkan belajar mereka. Siswa dalam penelitian melaporkan kesukaan mereka karena mampu melanjutkan dengan dengan langkah mereka sendiri, dan waktu yang disesuaikan dengan kemampuan mereka sendiri, download bahan mengajar, mereka ulangi dengan modul sebagai sebanyak yang diperlukan. Tujuh prinsip praktik yang baik 
dengan penekanan pada teknologi memberikan kerangka kohesif untuk instruksi secara online yang berkualitas (12).

Berdasarkan latar belakang yang telah disampaikan di atas, peneliti tertarik untuk membuat penelitian yang bertujuan untuk: 1) Mendeskripsikan karakteristik pengembangan $e$-modul berbasis web sebagai bahan ajar fisika pada materi gelombang bunyi yang dihasilkan, dan 2) Mendeskripsikan kelayakan pengembangan $e$-modul berbasis web sebagai bahan ajar fisika pada materi gelombang bunyi.

\section{METODE PENELITIAN}

Metode yang digunakan dalam penelitian ini adalah metode Research and Development (R\&D). Metode R\&D (Research and Development) adalah metode penelitian yang digunakan untuk menghasilkan produk tertentu dan menguji keefektifan produk tersebut (13).

Pada penelitian ini menggunakan model pengembangan 4-D. Model ini terdiri dari 4 tahap pengembangan, yaitu Define, Design, Develop, dan Disseminate atau diadaptasi menjadi model 4P, yaitu Pendefinisian, Perancangan, Pengembangan, dan Penyebaran (14). Langkah-langkah penelitian dan pengembangan 3D dapat digambarkan seperti tertera pada Gambar 1.

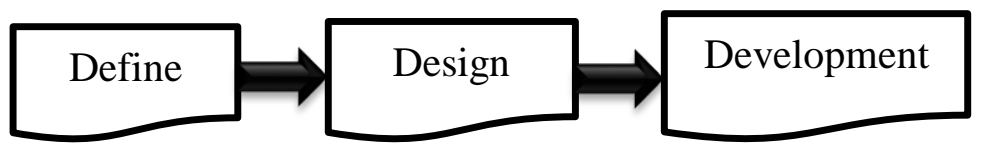

Gambar 1. Langkah-langkah Model 3D

Pada penelitian ini model 4-D yang digunakan hanya sebatas development atau pengembangan yang berupa uji terbatas. Instrumen yang digunakan dalam penelitian ini adalah lembar observasi, lembar angket kebutuhan dan lembar angket validasi ahli serta praktisi.

Pada lembar angket validasi, validator tidak akan menjawab salah satu jawaban kualitatif yang telah disediakan, tetapi menjawab salah satu jawaban kuantitatif yang telah disediakan. Analisis hasil uji validasi dilakukan secara deskriptif menggunakan rumus berikut.

$$
p=\frac{n}{N} \times 100 \%
$$

dengan $\mathrm{P}$ adalah persentase hasil uji validasi, $\mathrm{n}$ adalah skor total penilaian ahli, dan $\mathrm{N}$ adalah skor maksimal yang mungkin diperoleh (15).

Angket untuk validator dalam bentuk skala Likert menggunakan empat pilihan jawaban seperti yang tertera pada tabel 1 di bawah ini.

Tabel 1. Kriteria Penilaian Angket Validator

\begin{tabular}{cc}
\hline Interprestasi & Skor \\
\hline Sangat Baik (SB) & 4 \\
Baik (B) & 3 \\
Tidak Baik ( TB) & 2 \\
Sangat Tidak Baik (STB) & 1 \\
\hline
\end{tabular}

\section{HASIL DAN PEMBAHASAN}

\subsection{Deskripsi Hasil Pengembangan}

\subsubsection{Define (Pendefinisian)}

Kegiatan yang pertama yaitu analisis masalah yang dilakukan dengan melakukan observasi berdasarkan lembar observasi yang telah dibuat kemudian untuk mengidentifikasi kebutuhan siswa dilakukan dengan membagikan angket kebutuhan siswa menggunakan kuisioner online dengan berbantuan google forms. Berdasarkan hasil dari identifikasi kebutuhan dan karakteristik siswa, maka diperlukan pengembangan bahan ajar berbentuk elektronik pada materi gelombang bunyi sebagai bahan dan media belajar yang mendukung dalam proses pembelajaran yang berkriteria baik. Hal tersebut dapat kita lihat dari persentase rata -rata aspek tanggapan siswa sebesar $79 \%$ yang 
dikategorikan sangat setuju. Maka dari itu perlu dikembangankan e-modul berbasis web sebagai bahan ajar fisika pada materi gelombang bunyi di SMA.

\subsubsection{Design (Perancangan)}

Pada tahap ini, peneliti menyiapkan segala sesuatu yang diperlukan oleh bahan ajar yang akan dikembangkan. Hal yang harus menjadi acuan agar bahan ajar yang dikembangkan memiliki kriteria yang baik adalah materi dan pokok - pokok subbab dari materi yang akan disampaikan pada siswa harus relevan dan sesuai dengan KD dan indikator serta tujuan pembelajaran yang harus dikuasai oleh siswa. Setelah perangkat dan materi ditentukan, maka bahan ajar dibuat sesuai dengan analisis kebutuhan dan rancangan.

\subsubsection{Develop (Pengembangan)}

Pada tahap pengembangan ini, peneliti melakukan 2 tahap pengembangan yaitu, membuat produk awal modul dan produk awal pada sistem web. Produk awal yang dihasilkan dari peneliti ini yaitu sesuai dengan desain/kerangka awal yang telah dibuat. Adapun bagian-bagian dari produk awal bahan ajar yang dihasilkan adalah sebagai berikut.

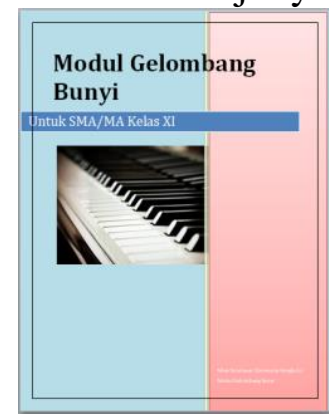

Gambar 2. Cover Modul



Gambar 3. Kata Pengantar



Gambar 4. KD, Indikator, dan Tujuan

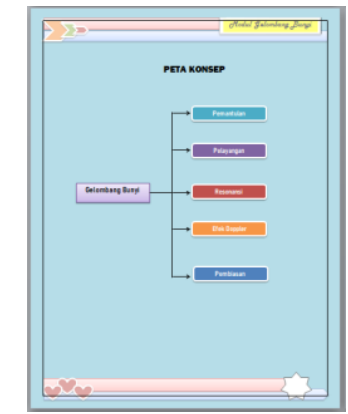

Gambar 5. Peta Konsep

Pembelajaran

Pada bagian awal modul terdapat cover yang berisi judul modul, kata pengantar, kompetensi inti, kompetensi dasar, indikator, tujuan pembelajaran dan peta konsep.



Gambar 6. Materi



Gambar 7. Contoh Soal dan Info Fisika

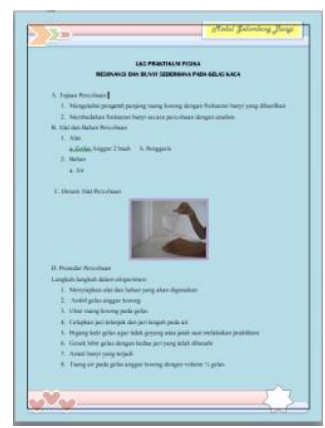

Gambar 8. Lembar Kerja Siswa

Modul dilengkapi dengan materi, contoh soal, info fisika, serta lembar kerja siswa.



Gambar 9. Rangkuman

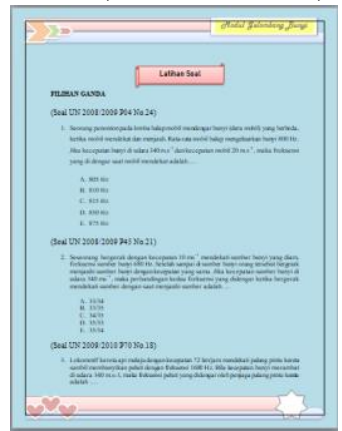

Gambar 10. Tes Formatif



Gambar 11. Daftar

Pustaka

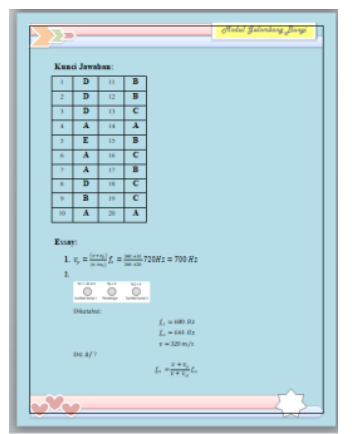

Gambar 12. Kunci Jawaban

Pada bagian akhir modul terdapat rangkuman, tes formatif, daftar pustaka, dan kunci jawaban yang dapat membantu siswa memeriksa apakah yang dikerjakannya sudah benar. Berikut adalah tampilan dari web, Tampilan awal pada produk ini berisi artikel-artikel yang berhubungan dengan fisika. 

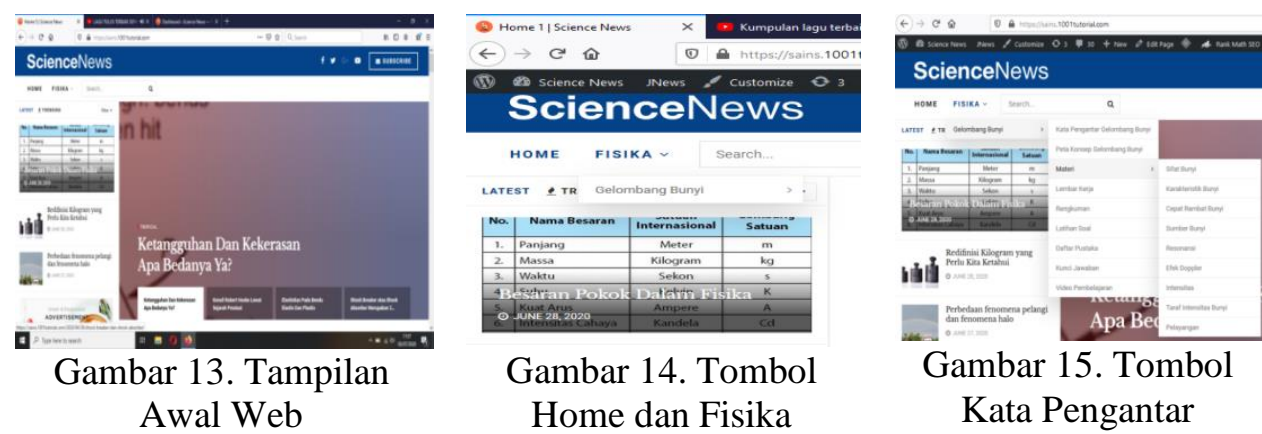

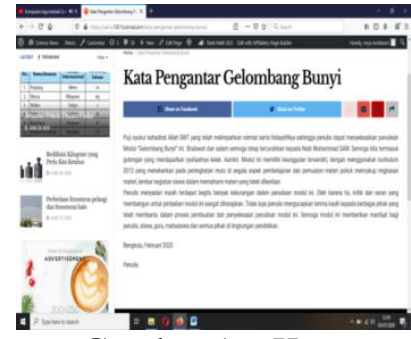

Gambar 16. Kata

Pengantar

Tampilan awal web bisa dilihat pada gambar 13. Di dalam web terdapat tombol-tombol seperti tombol home dan tombol kata pengantar yang ketika di klik akan membuka jendela kata pengantar.

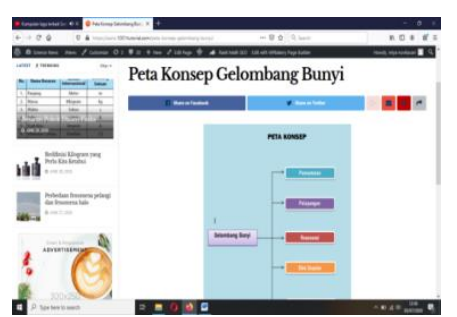

Gambar 17. Peta Konsep

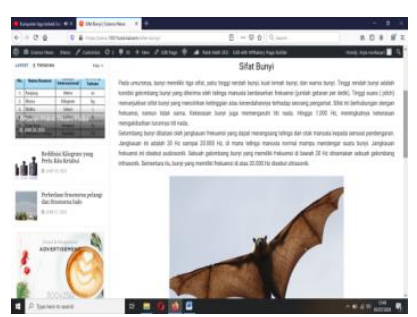

Gambar 18. Materi

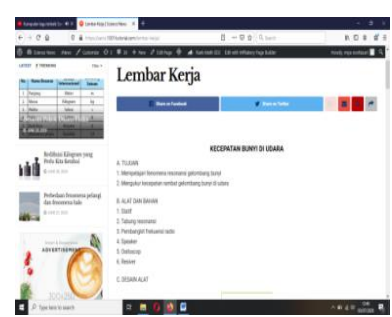

Gambar 19. Lembar Kerja

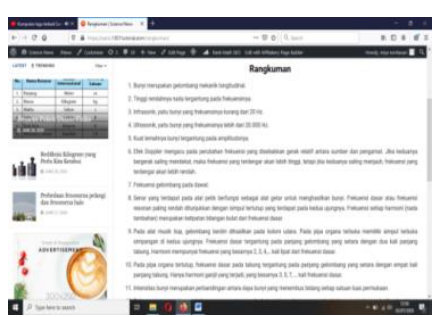

Gambar 20. Rangkuman

Di dalam web juga ditampilkan peta konsep, materi, lembar kerja, serta rangkuman dari materi yang dipilih yaitu subbab dari materi gelombang bunyi.



Gambar 21. Latihan Soal

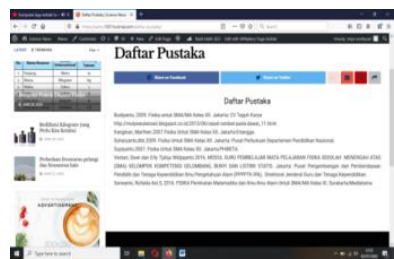

Gambar 22. Daftar

Pustaka

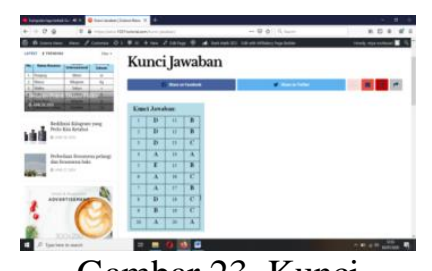

Gambar 23. Kunci

Jawaban

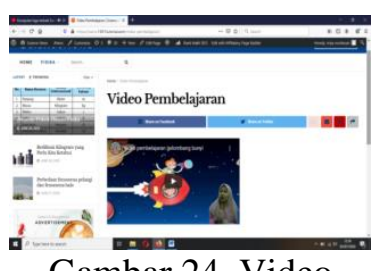

Gambar 24. Video Pembelajaran

Terdapat juga latihan soal, daftar pustaka, kunci jawaban serta video pembelajaran yang semakin menambah daya tarik. Kegiatan selanjutnya adalah validasi produk, aspek yang dinilai ada 4 yaitu aspek isi, penyajian, bahasa, dan media.

Tabel 2. Hasil Uji Validitas Aspek Kelayakan Isi oleh Ahli

\begin{tabular}{ccccc}
\hline Validator & $\begin{array}{c}\text { Skor Total } \\
\text { (n) }\end{array}$ & $\begin{array}{c}\text { Skor Maksimal } \\
(\mathbf{N})\end{array}$ & $\begin{array}{c}\text { Persentase } \\
P=\frac{n}{N} \times 100 \%\end{array}$ & Kategori \\
\hline Ahli I & 34 & 40 & $85 \%$ & Sangat baik \\
Ahli II & 31 & 40 & $77 \%$ & Sangat baik \\
Rata-Rata & 32,5 & 40 & $81 \%$ & Sangat baik \\
\hline
\end{tabular}

Berdasarkan tabel 2 menunjukkan bahwa hasil uji validasi aspek kelayakan isi yang dilakukan oleh judgement ahli I dan II terhadap bahan ajar elektronik pada materi Gelombang Bunyi yang sudah dibuat berada dalam kategori sangat baik dengan persentase $81 \%$ dari $100 \%$.

Tabel 3. Hasil Uji Validitas Aspek Kelayakan Isi oleh Praktisi

\begin{tabular}{ccccc}
\hline Validator & $\begin{array}{c}\text { Skor Total } \\
\text { (n) }\end{array}$ & $\begin{array}{c}\text { Skor Maksimal } \\
(\mathbf{N})\end{array}$ & $\begin{array}{c}\text { Persentase } \\
P=\frac{n}{N} \times 100 \%\end{array}$ & Kategori \\
\hline Praktisi I & 31 & 40 & $77 \%$ & Sangat baik \\
Praktisis II & 30 & 40 & $75 \%$ & Baik \\
Rata-Rata & 30,5 & 40 & $76 \%$ & Sangat baik \\
\hline
\end{tabular}


Pada tabel 3 menunjukkan bahwa aspek kelayakan isi yang dilakukan oleh praktisi pada bahan ajar elektronik pada materi Gelombang Bunyi yang sudah dibuat diketahui bahwa berada dalam kategori sangat baik dengan presentase $76 \%$.

Tabel 4. Hasil Uji Validitas Aspek Penyajian olah Judgment Ahli

\begin{tabular}{ccccc}
\hline Validator & $\begin{array}{c}\text { Skor Total } \\
(\mathbf{n})\end{array}$ & $\begin{array}{c}\text { Skor Maksimal } \\
(\mathbf{N})\end{array}$ & $\begin{array}{c}\text { Persentase } \\
P=\frac{n}{N} \times 100 \%\end{array}$ & Kategori \\
\hline Ahli I & 12 & 16 & $75 \%$ & Baik \\
Ahli II & 12 & 16 & $75 \%$ & Baik \\
Rata-Rata & 12 & 16 & $75 \%$ & Baik \\
\hline
\end{tabular}

Berdasarkan tabel 4 menunjukkan bahwa pada aspek penyajian yang dilakukan oleh judgment ahli I dan ahli II terhadap bahan ajar elektronik pada materi gelombang bunyi yang dikembangkan berada dalam kategori baik dengan persentase $75 \%$ dari $100 \%$.

Tabel 5. Hasil Uji Validitas Aspek Penyajian oleh Praktisi

\begin{tabular}{ccccc}
\hline Validator & $\begin{array}{c}\text { Skor Total } \\
(\mathbf{n})\end{array}$ & $\begin{array}{c}\text { Skor Maksimal } \\
(\mathbf{N})\end{array}$ & $\begin{array}{c}\text { Persentase } \\
P=\frac{n}{N} \times 100 \%\end{array}$ & Kategori \\
\hline Praktisi I & 12 & 16 & $75 \%$ & Baik \\
Praktisi II & 13 & 16 & $81 \%$ & Sangat baik \\
Rata-Rata & 12,5 & 16 & $78 \%$ & Sangat baik \\
\hline
\end{tabular}

Pada tabel 5 menunjukkan bahwa validasi aspek penyajian yang dilakukan oleh praktisi I dan II terhadap bahan ajar elektronik pada materi gelombangan bunyi yang dikembangkan sudah berada dalam kategori sangat baik dengan persentase $78 \%$.

Tabel 6. Hasil Validitas Aspek Bahasa oleh judgment Ahli

\begin{tabular}{ccccc}
\hline Validator & $\begin{array}{c}\text { Skor Total } \\
(\mathbf{n})\end{array}$ & $\begin{array}{c}\text { Skor Maksimal } \\
(\mathbf{N})\end{array}$ & $\begin{array}{c}\text { Persentase } \\
P=\frac{n}{N} \times 100 \%\end{array}$ & Kategori \\
\hline Ahli I & 25 & 28 & $89 \%$ & Sangat baik \\
Ahli II & 21 & 28 & $75 \%$ & Baik \\
Rata-Rata & 23 & 28 & $82 \%$ & Sangat baik \\
\hline
\end{tabular}

Pada tabel 6 menunjukkan bahwa aspek bahasa yang dilakukan oleh judgement ahli I dan ahli II terhadap bahan ajar elektronik menggunakan website yang dikembangkan berada dalam kategori sangat baik dengan persentase $82 \%$ dari $100 \%$.

Tabel 7. Hasil Uji Validitas Aspek Bahasa oleh Praktisi

\begin{tabular}{ccccc}
\hline Validator & $\begin{array}{c}\text { Skor Total } \\
(\mathbf{n})\end{array}$ & $\begin{array}{c}\text { Skor Maksimal } \\
(\mathbf{N})\end{array}$ & $\begin{array}{c}\text { Persentase } \\
\boldsymbol{P}=\frac{n}{N} \times 100 \%\end{array}$ & Kategori \\
\hline Praktisi I & 21 & 28 & $75 \%$ & Baik \\
Praktisi II & 21 & 28 & $75 \%$ & Baik \\
Rata-Rata & 21 & 28 & $75 \%$ & Baik \\
\hline
\end{tabular}

Berdasarkan tabel 7 menunjukkan bahwa validasi yang dilakukan oleh praktisi I terhadap bahan ajar elektronik yang dkembangkan berada dalam baik dengan persentase $75 \%$. Sedangkan penilaian praktisi II didapatkan hasil bahwa aspek bahasa bahan ajar elektronik yang dikembangkan berada dalam kategori baik dengan persentase $75 \%$.

Tabel 8. Hasil Uji Validitas Aspek Media oleh judgment Ahli

\begin{tabular}{ccccc}
\hline Validator & $\begin{array}{c}\text { Skor Total } \\
(\mathbf{n})\end{array}$ & $\begin{array}{c}\text { Skor Maksimal } \\
(\mathbf{N})\end{array}$ & $\begin{array}{c}\text { Persentase } \\
P=\frac{n}{N} \times 100 \%\end{array}$ & Kategori \\
\hline Ahli I & 26 & 36 & $72 \%$ & Baik \\
Ahli II & 27 & 36 & $75 \%$ & Baik \\
Rata-Rata & 26,5 & 36 & $74 \%$ & Baik \\
\hline
\end{tabular}

Pada tabel 8 menunjukkan bahwa aspek media terdiri dari 9 butir penilaian yang harus terpenuhi. Validitas aspek media yang dilakukan oleh judgment ahli I dan ahli II diketahui bahwa aspek media 
pada bahan ajar elektronik menggunakan website yang dikembangkan berada dalam kategori baik dengan persentase $74 \%$ dari $100 \%$.

Tabel 9. Hasil Uji Validitas Aspek Media oleh Praktisi

\begin{tabular}{ccccc}
\hline Validator & $\begin{array}{c}\text { Skor Total } \\
(\mathbf{n})\end{array}$ & $\begin{array}{c}\text { Skor Maksimal } \\
(\mathbf{N})\end{array}$ & $\begin{array}{c}\text { Persentase } \\
\boldsymbol{P}=\frac{n}{N} \times 100 \%\end{array}$ & Kategori \\
\hline Ahli I & 27 & 36 & $75 \%$ & Baik \\
Ahli II & 29 & 36 & $80 \%$ & Baik \\
Rata-Rata & 28 & 36 & $77 \%$ & Baik \\
\hline
\end{tabular}

Berdasarkan tabel 9 validasi aspek isi praktisi I dan II didapatkan hasil bahwa aspek media pada bahan ajar eletronik menggunakn website yang dikembangkan sudah berada dalam kategori sangat baik dengan persentase $77 \%$.

\subsection{Pembahasan}

Penelitian ini bertujuan untuk mengembangkan bahan ajar fisika dalam bentuk elektronik menggunakan website pada materi Gelombang Bunyi. Langkah pertama yang dilakukan adalah mengidentifikasi analisis kebutuhan. Pada penelitian ini, untuk mengetahui kebutuhan dari bahan ajar di SMA N 2 Kota Bengkulu dilakukan dengan observasi. Hasil observasi yaitu di sekolah tersebut telah menerapkan kurikulum 2013, dimana pada kurikulum 2013 lebih menuntut siswa untuk aktif selama proses pembelajaran dan harus mencari informasi sendiri, sehingga guru harus menciptakan suasana belajar yang dapat membuat siswa menemukan dan mencari informasi dengan sendirinya sehingga adanya aktivitas selama proses pembelajaran, salah satunya yaitu dengan membuat bahan ajar yang menarik sehingga menimbulkan daya tarik belajar siswa.

Pengumpulan informasi analisis kebutuhan pada penelitian ini menggunakan lembar analisis kebutuhan siswa (Lampiran 3) yang disebar ke 3 sekolah yaitu SMA N 2 Kota Bengkulu, SMA N 4 Kota Bengkul, dan SMA N 6 Kota Bengkulu sebanyak 75 siswa. Penyebaran angket ini dilakukan dengan menggunakan kuisioner online berbantuan google forms. Berdasarkan hasil analisis kebutuhan diketahui bahwa dalam proses pembelajaran fisika di tiga sekolah tersebut, masih menggunakan bahan ajar berupa buku cetak dan belum memanfaatkan teknologi dan menurut mereka sangat diperlukan sebuah bahan ajar alternatif yang menuju pada perkembangan teknologi.

Langkah selanjutnya yang dilakukan adalah desain produk. Untuk mendesain produk berupa bahan ajar elektronik dilakukan dengan beberapa tahapan yaitu memilih media pembelajaran, mendesain materi dan bahan ajar. Penyusunan materi bahan ajar diawali dengan silabus, dan kompetensi dasar. Berdasarkan silabus, kompetensi dasar pada materi gelombang bunyi yaitu: Menerapkan konsep dan prinsip gelombang bunyi dalam teknologi. Selanjutnya yaitu mendesain format bahan ajar yang terdiri dari cover, kata pengantar, peta konsep, pendahuluan, kegiatan praktikum, dan daftar isi. Setelah itu peneliti juga menyiapkan media yang akan digunakan, media yang digunakan pada bahan ajar ini yaitu sebuah website yang berisi materi tentang Gelombang Bunyi. Sebelum menginput materi gelombang bunyi, peneliti terlebih dahulu menyiapkan dan menginput artikel-artikel yang berhubungan dengan fisika supaya kualitas website yang digunakan lebih baik.

Karakteristik bahan ajar yang dibuat yaitu menyajikan bahan ajar non cetak atau berbentuk elektronik dengan bantuan website sehingga bahan ajar yang dikembangkan akan disajikan semenarik mungkin serta jelas sehingga memudahkan siswa untuk belajar fisika khususnya materi gelombang bunyi dimanapun dan kapanpun siswa bisa mengakses materi melalui website yang telah disediakan. Pada bahan ajar elektronik ini juga terdapat video pembelajaran disetiap subbab yang mampu membantu memperjelas materi yang tidak bisa tersampaikan lewat tulisan sehingga melalui video dapat tervisualisasikan dengan jelas. Dengan demikian menimbulkan ketertarikan siswa terhadap fisika yang selama ini kebanyakan orang beranggapan bahwa fisika merupakan pelajaran yang sulit sehingga paradigma itu dapat dihilangkan dengan adanya bahan ajar ini.

Setelah tahap desain produk maka tahap selanjutnya yang dilakukan yaitu validasi desain produk. Validasi desain merupakan tahap penilian judgement ahli. Tahap ini dilakukan untuk 
mengetahui kevalidan bahan ajar elektronik yang dikembangkan. Uji validitas untuk produk ini dilakukan oleh 2 judgement ahli (Dosen), dan validasi untuk produk ini juga dilakukan oleh 2 praktisi (Guru). Pada penelitian ini validasi dilakukan dengan menggunakan 4 aspek yaitu penyajian, isi, bahasa, dan media.

Berdasarkan hasil rata-rata uji validasi oleh judgement ahli dan praktisi persentase penilaian aspek bahasa yaitu 78\% yang berada pada kategori sangat baik. Aspek bahasa memiliki 7 butir penilaian, berdasarkan hasil rata-rata uji validasi oleh ahli dan praktisi persentase penilaian aspek bahasa yaitu $78 \%$ yang berada pada kategori sangat baik yang mengacu pada interpretasi skala likert. Dari hasil tersebut dapat mencerminkan bahwa bahan ajar elektronik yang dikembangkan telah menggunakan bahasa yang baik, ketepatan struktur kalimat, kefektifan kalimat, ketepatan penggunaan kaidah bahasa, kemampuan memotivasi, keruntutan dan keterpaduan antar paragraph, konsistensi penggunaan istilah dan konsistensi penggunaan symbol atau ikon yang baik sehingga bahan ajar yang dikembangkan sudah berada pada tahap layak digunakan.

Masukan atau saran dari validator digunakan sebagai acuan untuk melalukan revisi. Revisi yang dilakukan yaitu pada aspek isi dimana adanya kesalahan dalam pengetikan kata, kurang besarnya tampilan rumus pada website, mengganti gambar yang lebih spesifik pada materi. Aspek bahasa tidak dilakukan revisi karena berdasarkan uji validitas aspek bahasa berada dalam kategori sangat baik. Kerangka bahan ajar yang sudah dikembangkan juga tidak mengalami revisi karena pada aspek penyajian mendapatkan persentase $77 \%$ dengan kategori sangat baik dan tidak adanya saran dari validator sehingga kerangka akhir bahan ajar mengacu pada kerangka yang sudah dikembangkan.

Berdasarkan hasil total dari uji validasi aspek penyajian, isi, bahasa, dan media yang dilakukan oleh 2 judgement ahli dan 2 orang praktisi maka dapat dikatakan bahwa bahan ajar elektronik (e-modul) menggunakan Website yang sudah dikembangkan tergolong dalam kategori sangat baik dengan persentase rata-rata yaitu $78 \%$ dari $100 \%$. Hal ini berarti bahan ajar elektronik (e-modul) fisika yang dikembangkan sudah memenuhi aspek penyajian, isi, media dan bahasa sehingga dapat disimpulkan bahwa bahan ajar elektronik (e-modul) dengan menggunakan website yang sudah dikembangkan merupakan desain teruji. Penilaian akhir dari setiap validator adalah bahan ajar yang sudah dikembangkan sudah layak akan tetapi perlu adanya revisi.

Penelitian ini relevan dengan penelitian yang dilakukan oleh Annisa Sabrina dan Rahma Diani (2019) dengan judul "Pengembangan Media Pembelajaran Fisika Berbasis Web Enhanced Course Dengan Model Inkuiri Terbimbing" yang memperoleh rata-rata persentase ahli materi $87,45 \%$, ahli media $83,61 \%$, dan ahli informatika sebesar $77,29 \%$. Berdasarkan tabel kriteria penilaian media pembelajaran yang dikembangkan termasuk kedalam kategori "sangat baik" (17). Selain itu juga relevan dengan penelitian yang dilakukan oleh Taufik Solihudin JH (2018) yang berjudul "Pengembangan E-Modul Berbasis Web untuk Meningkatkan Pencapaian Kompetensi Pengetahuan Fisika pada Materi Listrik Statis dan Dinamis Sma". Pada penelitian Solihudin komponen yang ada pada e-modul bisa diadopsi dari komponen modul cetak. Komponenkomponen utama yang perlu tersedia adalam modul yaitu, kata pengantar, peta konsep, tes formatif, kunci jawaban, rangkuman, dan daftar pustaka. Selanjutnya pada penelitiannya media yang digunakan berupa website. Hasil dari rata-rata persentase ahli media $78,13 \%$, dan ahli materi sebesar $81,82 \%$ pada interpretasi baik dan layak, dari hasil tersebut dapat disimpulkan bahwa produk pengembangan layak digunakan untuk proses pembelajaran (11), karena pada penelitian ini menu yang ditampilkan pada website belum mencakup komponen yang terdapat pada modul dan belum membahas tentang materi gelombang bunyi maka peneliti melakukan penelitian ini dengan materi yang berbeda dan tambahan menu pada tampilan website serta terdapat video pembelajaran yang ada disetiap subbab materi.

Kendala-kendala yang dihadapi saat mengembangkan bahan ajar elektronik adalah mendesain bahan ajar, pembuatan dan pengeditan video pembelajaran yang dalam proses pembuatan video harus di ruangan yang kedap suara atau dalam keadan sepi supaya suara dari luar tidak masuk ke dalam video tersebut, serta mengolah website untuk membuat tampilan dan isi yang 
semenarik mungkin. Adapun kelebihan produk akhir yang sudah dikembangkan yaitu dapat diakses melalui komputer dan handphone dengan jaringan internet yang memadai.

\section{SIMPULAN DAN SARAN}

\subsection{Simpulan}

Karakteristik bahan ajar elektronik yang dikembangkan yaitu e-modul berbentuk elektronik dengan bantuan Website yang dapat diakses dengan menggunakan laptop atau handphone. Dalam bahan ajar elektronik terdapat video pembelajaran di setiap subab materi pelajaran. Video pembelajaran tersebut dapat dilihat dengan cara mengklik pada bagian video yang sudah disediakan di laman website, maka dengan otomatis video akan terputar di youtube. Menu-menu yang ada di dalam website tersebut dilengkapi dengan kata pengantar, peta konsep, materi, kata kunci, contoh soal, lembar kerja siswa, rangkuman, tes formatif, kunci jawaban tes formatif dan daftar pustaka sama halnya yang terdapat pada modul seperti biasanya. Berdasarkan hasil validasi oleh judgment ahli dan praktisi, bahan ajar elektronik yang dikembangkan termasuk dalam kategori layak diuji cobakan karena mendapatkan respon positif dengan persentase rata-rata $78 \%$ dengan kategori sangat baik.

\subsection{Saran}

Video pembelajaran yang ada pada subbab materi masih menggunakan video milik orang lain yang di akses di youtube dan pada menu video pembelajaran terdapat video yang membahas secara keseluruhan tidak perbab, untuk penelitian selanjutnya dapat membuat video pembelajaran yang disampaikan sendiri oleh peneliti, dan dibuat dengan perbab, Pada instrumen validasi ahli jumlah item pada setiap indikatornya hanya memiliki satu item saja, seharusnya lebih dari satu, minimal dua. Maka dari itu untuk penelitian selanjutnya perlum memperhatikan jumlah item yang digunakan untuk intrumen penelitian, Lakukan penelitian dan pengembangan bahan ajar elektronik berbasis web dengan materi yang berbeda dan terdapat banyak materi dalam satu website.

\section{UCAPAN TERIMA KASIH}

Penulis mengucapkan terimakasih kepada validator ahli dan praktisi yang sudah bersedia untuk membantu pengisian angket validasi pengembangan $e$-modul berbasis web sebagai bahan ajar fisika pada materi gelombang bunyi

\section{DAFTAR PUSTAKA}

1. Khasanah SM, Supardi I. PENGEMBANGAN LKPD BERBASIS PENDEKATAN SAINTIFIK UNTUK MELATIHKAN KETERAMPILAN BERPIKIR KRITIS. IPF InOv Pendidik Fis. 2019;08(03):799-803.

2. Alawiyah R. PENERAPAN SIKAP “ STUDENT LEADERSHIP ” ( KEPEMIMPINAN SISWA ) UNTUK MENINGKATKAN SIKAP MANDIRI DAN. Pros Semin dan Disk Nas Pendidik Dasar. 2018;125-33.

3. Usman U. Komunikasi Pendidikan Berbasis Blended Learning Dalam Membentuk Kemandirian Belajar. J Jurnalisa. 2018;4(1):136-50.

4. Yushardi, Wahyuni T, Wahyuni S. Pengembangan Modul Multimedia Interaktif Berbasis ELearning Pada Pokok Bahasan. Pembelajaran Fis. 2017;6(4):404-10.

5. Paradina D, Connie C, Medriati R. Pengaruh Model Pembelajaran Problem Based Learning Terhadap Hasil Belajar Siswa Di Kelas X. J Kumparan Fis. 2019;2(3):169-76.

6. Sukiminiandari YP, Budi AS, Supriyati Y. Pengembangan Modul Fisika dengan Pendekatan Saintifik. Pros Semin Nas Fis. 2015;IV:161-4.

7. Mertayasa INE, Agustini K, Santyasa IW. Efektivitas E-Modul Berorientasi Modalitas Gaya Belajar Pada Mata Pelajaran Komunikasi Data Kelas XI TKJ di SMK Negeri 3 Singaraja. Semin Nas Pendidik Tek Inform. 2018;9(September):81-4. 
8. Nurohman S, Suyoso. Pengembangan Modul Elektronik Berbasis Web Format Mobile Version Sebagai Media Pembelajaran Fisiska dapat diakses melalui Smartphone Platform Android. 2014;4:1-13.

9. Johar A, Risdianto E, Indriyati DAF. Perancangan Dan Implementasi Media Pembelajaran Berbasis Web Pada Bidang Studi Bahasa Inggris Di Kelas Vii Smp Negeri 1 Kota Bengkulu Dengan Menggunakan Php Dan Mysql. Rekursif. 2014;2(1):1-9.

10. Sakti I, Puspasari YM, Risdianto E. PENGARUH MODEL PEMBALAJARAN LANGSUNG (Direct Instruction) MELALUI MEDIA ANIMASI BERBASIS MACROMEDIA FLASH TERHADAP MINAT BELAJAR DAN PEMAHAMAN KONSEP FISIKA SISWA DI SMA PLUS NEGERI 7 KOTA BENGKULU. Exacta. 2012;10(1):1-10.

11. Solihudin JH T. Pengembangan E-Modul Berbasis Web Untuk Meningkatkan Pencapaian Kompetensi Pengetahuan Fisika Pada Materi Listrik Statis Dan Dinamis Sma. WaPFi (Wahana Pendidik Fis. 2018;3(2):51-61.

12. Purwaningtyas WDD, Hariyadi I. Pengembangan Modul Elektronik Berbasis Online Dengan Program Edmodo. J Pendidik. 2017;2(1):123, 121-9.

13. Sugiyono. Metode Penelitian \& Pengembangan ( Research and Development/ R \& D). Bandung: ALFABETA; 2018.

14. Ernawati. PENGEMBANGAN PERANGKAT PEMBELAJARAN BERDASARKAN MODEL 4-D PADA MATERI GETARAN GELOMBANG DAN BUNYI DALAM MENINGKATKAN PEMAHAMAN KONSEP SISWA SMP NEGERI 6 PALU. J Sains dan Teknol Tadulako. 2014;3(1):62-71.

15. RIZAL M. PENGEMBANGAN LKPD MATEMATIKA BERBASIS PROBLEM BASED LEARNING UNTUK MENINGKATKAN KEMAMPUAN HIGHER ORDER THINKING SKILLS PESERTA DIDIK KELAS IV SD. UNIVERSITAS LAMPUNG; 2018.

16. Fitri H, Maison, Kurniawan DA. Pengembangan e-modul menggunakan 3D pageflip profesional pada materi momentum dan impuls SMA/MA kelas XI. Edufisika J Pendidik Fis. 2019;4(1):1-12.

17. Shabrina A, Diani R. Pengembangan Media Pembelajaran Fisika Berbasis Web Enhanced Course dengan Model Inkuiri Terbimbing. Indones J Sci Math Educ. 2019;2(1):9-26. 